\title{
The Impact of the Quality of Integrated Reporting Disclosure on Corporate Reputation
}

\author{
Mira Susanti Amirrudin', Mazni Abdullah ${ }^{2 *}$ and Zakiah Saleh ${ }^{2}$ \\ ${ }^{1}$ Faculty of Accountancy, Universiti Teknologi MARA, Malaysia \\ ${ }^{2}$ Faculty of Business \& Accountancy, Universiti Malaya, Malaysia
}

\begin{abstract}
In 2013, the International Integrated Reporting Council (IIRC) issued the Integrated Reporting (IR) Framework to improve corporate reporting. The purpose of IR is to integrate financial and non-financial information to explain how the organisation creates value and improves firm performance over time. Since the introduction of IR, a company weighs the benefits over the costs of changing to IR. Recent trends in IR have heightened the need to examine the actual contents of IR. The objective of this study was to find the relationship between preparing a high-quality IR and corporate reputation. Corporate reputation is one of the main objectives for the preparation of IR, and preparing a high-quality IR can positively impact corporate reputation. Data was collected from a sample of 120 companies from the IIRC websites for three years (360 firm-year observations) to examine the quality of following the 2013 Framework. An index was developed, and the corporate reputation score was collected from the RepTrak websites. The finding showed that companies preparing high-quality IR reports had a significant positive relationship with corporate reputation. Preparing a highquality IR sends a signal to users of annual reports as a connotation of the company (good product or services, ethical management reporting), which will help build trust towards the company and improve its reputation. This study contributes by providing empirical evidence for a company, which is uncertain about the benefits of IR. The IR disclosure score can be used as a reference by IIRC and policymakers to prepare the IR.
\end{abstract}

Keywords: integrated reporting, disclosure quality, corporate reputation

\section{ARTICLE INFO}

Article History:

Received: 16 February 2021

Accepted: 4 June 2021

Published: 1 December 2021

* Corresponding author: Mazni Abdullah. Email: mazni@um.edu.my 


\section{INTRODUCTION}

Integrated Reporting (IR) is a new reporting tool developed and promoted by the International Integrated Reporting Council to improve corporate reporting. The issuance of the IR Framework in 2013 provides guiding principles for an organisation on how to link financial and non-financial information, organisation's strategy, governance, and which will create value over time (IIRC, 2013b). IR promotes transparency in corporate reporting, greater accessibility of information towards capital and requires a strong commitment to sustainability strategy.

Therefore, having an idea of the actual content of IRs and its quality after the IR Framework issuance in 2013 is vital to understand the development of content elements in the IR report since 2013. Analysis of the IR content will help new companies intending to change their report into IR to have guidance on what is considered a good quality IR report. A growing body of literature recognises the importance of a good quality IR to its users. Previous research comparing quality of IR disclosure and firm performance found that a good quality IR can create value for a firm (Pavlopoulos et al., 2019), increases the quality of reported earnings per share (Cortesi \& Vena, 2019), and reduces the cost of equity (Zhou et al., 2015).

The impact of good quality IR on corporate reputation is indeed a practical matter. Companies need to be sure that changing to IR will bring benefits regarding corporate reputation or firm performance. Changing to IR is a costly decision, and there is a need to ensure that the benefits of IR outweigh its costs. The adoption and understanding of the impact of IR report is an under-researched area that is of significant interest to be explored (Adams, 2015; Charl de Villiers et al., 2014; Eccles \& Krzus, 2010)

Understanding the impact of IR disclosure quality on performance will help an organisation weigh the benefits of adopting IR in preparing the annual report. Despite the growing interest and importance attached to IR, there has been limited research to explore the benefits of companies embracing IR as their reporting vehicle. This study provides empirical evidence on the benefits of adopting IR for corporate reputation using the Signalling Theory (ST). This study proves that preparing IR according to the IR Framework 2013 will reward companies by improving their corporate 
reputation. Drawing on a sample from IIRC websites of self-declared IR reports, this study employed a regression model to understand the impact of IR on corporate reputation.

The International Integrated Reporting Council (IIRC) has developed an Integrated Reporting (IR) Framework to integrate financial and nonfinancial information better and improve corporate reporting. The IR Framework was established in December 2013 by the IIRC to promote integrated thinking and change business behaviour. The IR shows the holistic picture of future targets and links between financial and non-financial performances (Jensen \& Berg, 2012). In favour of IR, practitioners and supporters of IR assert that IR brings more transparency on a corporate commitment to sustainability by showing the links between financial and sustainable performance in a single document (Adam, 2017; Eccles \& Krzus, 2010). The adoption of a quality IR can positively impact financial performance and firm value and indirectly its corporate image and reputation (Vitolla et al., 2019).

The impact of IR on corporate reputation is indeed a practical matter. Changing to IR is a costly decision, and there is a need to ensure that the benefits of IR outweigh its costs. Corporate reputation can regulate corporate behaviour and is a source of competitive advantage that reflects the perception of multiple stakeholders (Darus et al., 2014). This study adopted the ST (Galbreath \& McDonald, 2010; Hasseldine et al., 2005; Toms, 2002) which argues that companies engage in reputational building activities to signal their reputation to stakeholders through their strategic choices and activities.

Researchers have studied corporate reputation as one of the variables to explain the benefits of disclosure, and companies disclose information in their report (e.g., Integrated Reporting) to signal their reputation to stakeholders. (Steyn, 2014) Interviews with CEOs and CFOs on IR implementation in Africa found that reputational aspects and corporate reputation improvements are regarded as IR's most significant benefit and outcome, suggesting that managers perceive IR as a valuable tool for legitimising corporate activities. Another research conducted by organisations in the IIRC Pilot Programme demonstrated that IR is perceived as a mechanism to articulate strategy and value creation activities, which resulted in improved corporate 
transparency and corporate reputation (IIRC, 2014). Researchers have also found that corporate reputation can attract employees and favourable capital and provide an advantage towards stakeholder relations (Arshad et al., 2012; Brammer \& Pavelin, 2006; Roberts \& Dowling, 2002). Firms with a relatively good reputation can better sustain superior profits over time, experience superior financial performances, and lower the cost of capital (Roberts \& Dowling, 2002; Wang \& Smith, 2008). Corporate reputation is essential in this study since the number of companies producing the IR is growing. The IIRC Pilot Programme started in 2011 with 40 organisations is now active in 25 countries. As of 2013, there were 140 leading business including Microsoft Corporation, Coca-Cola, and Volvo, joining this program (IIRC, 2014). Following the IIRC initiatives, the Global Reporting Initiative (GRI) conducted a GRI Corporate Leadership Group of Integrated Reporting program in 2015 to help leading organisations with IR. There is a need to assess whether the IR disclosures will have any impact on corporate reputation. Therefore, this study aimed to provide empirical evidence on the benefits of IR reporting by examining the relationship between quality of IR Disclosure and corporate reputation. This study drew a sample of IR companies from the IIRC websites. A total of 120 companies from the year 2014 to 2016 (360 firm-year observations) are selected for this study, comprising companies from voluntary and mandatory reporting countries.

\section{LITERATURE REVIEW}

According to the ST (Spence, 1973), the primary objective of corporate disclosure is to inform analysts and investors about a firm's quality and value. The ST suggests how a company gives signals to users through financial reports by disclosing financial and non-financial information that contain the results of management activities. The organisation will signal news to investors and other stakeholders, stating that the organisation is better than their competitors through voluntary disclosure (Oliveira et al., 2010).IR demonstrates how an organisation creates value by connecting strategic objectives, risks, and performance (IIRC, 2013b). IR requires companies to report in an integrated manner their commitment to value creation activities. Since IR disclosure is to inform the analysts and investors about firm quality and value, this suggests that disclosure decisions in the IR involve reporting only relevant information about firm performance. 
Therefore, if the IR is prepared by the IR Framework 2013, it signals a company's quality to their stakeholders and the signal received is shown through corporate reputation.

\section{Integrated Reporting Framework 2013}

In this Framework, the IR is defined as a concise communication about how an organisation's prospects, performance, governance, and strategy in the context of its external environment create value over the short, medium, and long-term (IIRC, 2013b) Table 1 shows that the Framework for IR consists of fundamental concepts, guiding principles, and content elements. The IR Framework introduces three fundamental concepts: the concept of the six capitals, the need to explain the organisation's business model, value creation and destruction over time. Capitals are categorised as financial, manufactured, intellectual, human, social and relationships, and natural capital. Although the Framework does not mandate that all the capital mentioned above apply to all organisations, it proposes that the categories mentioned earlier be used as a guideline to ensure that the company does not ignore the capital it uses or affects.

In the context of the IR, value is created through the business model of an organisation that takes input from the capitals and transforms it through business activities and interactions to generate results and outcomes that create or destroy value for the company, its stakeholders, community, and the environment in the short, medium and long term (IIRC, 2013a). The guiding principles inform the content of the integrated report of the strategic focus and future orientation, connectivity of information, stakeholder responsiveness, materiality and conciseness, reliability, completeness and consistency, and comparability (IIRC, 2013b). There are eight areas identified in the IR as a basis for its content elements. The importance of analysing the content elements of IRs is that they are considered essential factors for organisational value creation (IIRC, 2011). 
Table 1:IR Framework

\begin{tabular}{|c|c|c|}
\hline Fundamental concepts & Guiding principles & Content elements \\
\hline $\begin{array}{ll}\text { 1. } & \text { Capitals } \\
\text { - } & \text { Financial } \\
\text { - } & \text { Manufactured } \\
\text { - } & \text { Intellectual } \\
\text { - } & \text { Human } \\
\text { - } & \text { Social and } \\
& \text { relationship } \\
\text { - Natural } & \text { The Business } \\
\text { 2. } & \text { Model } \\
\text { 3. The Creation of } \\
\text { Value over time }\end{array}$ & 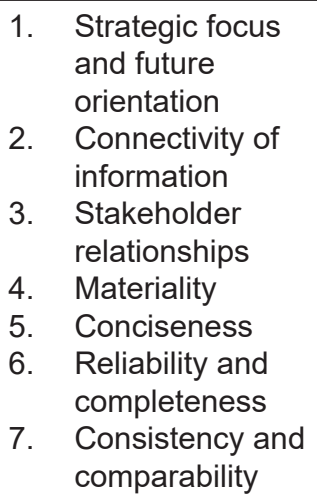 & 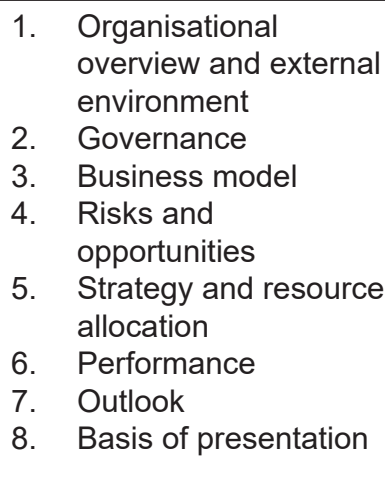 \\
\hline
\end{tabular}

\section{Corporate Reputation}

Corporate reputation connotes management commitment to ethical accounting and principled business practices (Wang \& Smith, 2008). A firm's reputation can be described as the organisational effectiveness of the firm (Landgraf \& Riahi-belkaoui, 2003). Stakeholders observe the organisational behaviours and actions taken by the organisation, and these observations create inferences about the organisation's station capabilities and characteristics (Basdeo et al., 2006). Many studies on disclosure and reputation used definition of reputation by Fombrun (1996), where where it is a perception representation of a company's past actions and prospects that describe a firm's overall appeal to all its key constituents compared to other leading rivals.

Reputation is vital for an organisation since it is a source of competitive advantage such as increased firm performance (Basdeo et al., 2006; Pham \& Tran, 2020), higher market value, and lower cost of capital (Wang \& Smith, 2008). Corporate reputation is an evaluation of the firm's quality(Love et al., 2017). The initiatives and strategies by an organisation create a positive perception by the stakeholders, which builds a better reputation(Pham \& Tran, 2020). Organisations disclose their initiatives in the annual report, such as corporate social responsibility activities, to show that the firm appears to be socially responsible and therefore creates a favourable judgment towards an organisation (Fombrun, 2005). 
This study follows adopted the ST (Galbreath, 2010; Hasseldine et al., 2005; Toms, 2002) which argues that companies engage in reputational building activities to signal their reputation to stakeholders through their strategic choices and activities. Toms (2002) used the quality ST on a sample of large listed UK firms in the UK to evaluate possible linkages between disclosure strategy and environmental reputation. This article suggests that instead of studying the disclosure based on quantity or volume, it is more important to study disclosure and its means. This argument is supported by Hasseldine et al. (2005) that instead of studying the disclosure based on volume or quantity, the qualitative nature (quality) of disclosure is more likely to enhance reputation. Accordingly, Hasseldine et al. (2005); Toms (2002) suggest that managers invest in disclosure activities to create a reputation. Steyn (2014) found that reputational aspects and corporate reputation improvement are regarded as the most significant benefit and outcome of IR, suggesting that managers perceive IR as a useful tool for legitimising corporate activities. Organisations in the IIRC Pilot Program demonstrated that IR could improve corporate transparency and reputation since companies must articulate strategy and the business model (IIRC, 2014). Dolphin (2004) stated that one of the critical weapons of organisational strategy formulation is to create a reputation.

Past empirical studies have examined the relationship between firms abilities such a CSR disclosure activities (environmental, social) and reputation (Landgraf \& Riahi-Belkaoui, 2003; Othman et al., 2015; Saeidi et al., 2015), Islamic CSR activities and corporate reputation (Arshad et al., 2012); and forward-looking disclosure and corporate reputation (Bravo et al., 2015). The content of IR requires a company to report the internal and external outcomes in their business model, and positive and negative effects of the activities in the company and explain how the company creates value.

Therefore, within the context of IR, the process of value creation is created through an organisation's business model, which takes input from the capitals and transforms them through business activities and interactions to produce outputs and outcomes that, over the short, medium, and long term, create or destroy value for the organisation, its stakeholders, society and the environment (IIRC, 2011, 2013b). Value creation in the IR provides visible signals for the IR user to infer a firm's positive characteristics. Preparing a high-quality IR means sending a signal to the user that the company can 
create value, and IR, therefore, is predicted to be a key mechanism for a firm to build its reputation. The hypothesis, was:

$\mathbf{H}_{1}$ : There is a positive relationship between the Total IR Disclosure Quality Index and corporate reputation.

\section{METHOD}

\section{Data Collection}

The sample for this study comprised 120 companies listed on the IIRC websites and self-declared as IR reporters. Samples were selected from the year 2014 to the year 2016 to examine the improvement of IR disclosure since the issuance of the IR Framework was in 2013. IIRC conducts no quality assessment on these IR reports, and companies are self-declaring that their annual report follows the 2013 IR Framework. The quality of IR reports measured by developing a Total Integrated Reporting Disclosures Quality (TIRDQ) Index consists of eight themes, and each theme consists of 10 items, which created a total of 80 items. The IR report quality ratings were based on previous studies, which measured the disclosure quality from 0 to 5(Toms, 2002). The maximum score of the IR report, therefore, was 400.

Previous studies have used different types of available corporate reputation scores, such as from Fortune Most Admired Company (Hasseldine et al., 2005; Toms, 2002), Reputation Track (Galbreath \& McDonald, 2010), or developing Corporate Reputation Index (Arshad et al., 2012). For this study, the reputation score was based on the RepTrack by Reputation Institute. RepTrack is the largest normative database for organisations to benchmark reputation management and provide decisionmaking context (Reptrak, 2016). RepTrack covers seven dimensions of reputation. The dimension for reputation covered under this RepTrack score is Products and Services, Innovation, Workplace, Governance, Citizenship, Leadership, and Performance. RepTrack provides a single score to measure the reputation of the companies, and this study measured IR corporate reputation referring to this single score. Previous studies have used RepTrack as a corporate reputation measure and suggested that RepTrack is a potentially powerful short-form measurement tool that can be used to: 
(1) assess perceptions of corporate reputation by both the general public and by specialised stakeholders; (2) compare corporate reputations across stakeholder groups; and (3) compare corporate reputations cross-culturally (Fombrun et al., 2015; Ponzi et al., 2011). The reputation data was collected from the websites https://insights.reputationinstitute.com/reptrak-reports. The reports were downloaded together with the reputation score for the year 2014 to the year 2016. The reputation score was in the range of 0 to 100 , which showed that a higher score represented a higher reputation. In the report, only a single score of reputation was available for public retrieval. Since this study only needed a reputation score, a single reputation score was used for the analysis.

\section{Research Model}

The relationship between the corporate reputation score (CORPRE) as the dependent variable and the Total Integrated Reporting Disclosure Quality (TIRDQ) index as an independent variable with size (SIZE), the board size (BSIZE), long term debts (LEV), industries (IND) and year of the report (YR) as control variables were tested using the ordinary least square method. The model for the study was as follows:

$\mathrm{CORPREP}=\alpha+\beta_{1} \mathrm{TIRDQ}+\beta_{2} \mathrm{SIZE}+\beta_{3} \mathrm{BSIZE}+\beta_{4} \mathrm{LEV}+\beta_{5} \mathrm{IND}+\beta_{5} \mathrm{YR}+\varepsilon$

CORPREP was the reputation score from 0-100 of IR companies, $\alpha$ was the intercept, TIRDQ was the index representing the quality of IR report, SIZE was the $\log _{10}$ of company total assets, BSIZE was the board size of the company, LEV was the leverage of the company measured as long term debt of the company, IND was the binary number of 0 and 1 to represents financial and non-financial companies, YR represented the year annual IR report was published and $\varepsilon$ was the error term.

\section{RESULTS AND DISCUSSION}

As shown in Table 2 the maximum score of the Total Integrated Reporting Disclosure TIRDQ index was 370, while the lowest was 160 , with an average of 265. The IR companies' reputation score ranged from 42 as the minimum to the maximum at 85 , and the average score was 65.8 . This study included 
industry classification (IND) dummy variables to control for industry effects (financial and non-financial) and year (YR) dummy variables to control for time effects. The industry was classified into two areas, financial and non-financial industries. The year control variable was for the year the IR report was issued -2014, 2015, and 2016. The other control variables were the size (measured based on the log of a total asset), board size (number of board members), leverage, industries, and the reporting year.

Table 2: Descriptive Analysis

\begin{tabular}{lccc} 
& Minimum & Maximum & Mean \\
\hline Total IR Disclosure Quality (TIRDQ) & 160 & 370 & 265.09 \\
Corporate Reputation Score (CORPSCORE) & 42.0000 & 85.0000 & 65.177222 \\
Size (SZ) & 5.26 & 9.24 & 7.2560 \\
Board Size (BSIZE) & 5.00 & 22.00 & 12.6472 \\
Long Term Debt (LEV) & 0.0420 & 55.7833 & 19.994097 \\
Industry (Financial/Non-Financial (IND) & 1.00 & 2.00 & 1.7861 \\
Year of the report (YR) & 1 & 3 & 2.00 \\
\hline
\end{tabular}

\section{Correlation and Regression}

Table 3 shows the correlation between TIRDQ, Corporate Reputation, and other variables included in the study, and Table 4 presents results for the association between TIRDQ, Corporate Reputation, and the control variables.

Table 3: Pearson Correlation between Variables

\begin{tabular}{lccccccc}
\hline & TIRDQ & REP & SIZE & BSZ & LEV & IND & YR \\
\hline TIRDQ & 1.00 & $.442^{* *}$ & $.213^{* *}$ & 0.03 & 0.10 & 0.07 & $-.204^{* *}$ \\
REP & & 1.00 & 0.05 & 0.03 & -0.01 & $.149^{* *}$ & -0.05 \\
SIZE & & & 1.00 & $.130^{*}$ & -0.07 & -0.09 & -0.04 \\
BSZ & & & & 1.00 & 0.05 & $.195^{* *}$ & 0.04 \\
LEV & & & & & 1.00 & $.360^{* *}$ & -0.04 \\
IND & & & & & & 1.00 & -0.01 \\
YR & & & & & & & 1.00 \\
\hline
\end{tabular}

${ }^{*}$. Correlation is significant at the 0.05 level (2-tailed). ${ }^{* \star}$. Correlation is significant at the 0.01 level (2-tailed)

As shown in Table 3 the correlation analysis showed that TIRDQ had a significant positive correlation $(\mathrm{r}=0.442, \mathrm{p}<0.01)$ with corporate reputation. 
There was also a significant positive correlation between TIRDQ and the size of the company $(\mathrm{r}=0.213, \mathrm{p}<0.01)$ but a significant negative correlation $(-0.204, \mathrm{r}<0.01)$ with the year of the report. The reputation score was a significant positive correlation with the industries. Subsequent regression analyses were performed on the TIRDQ and corporate reputation for identifying the relationship. The tests used included the F test, coefficient of determination, and test on regression coefficient.

Table 4 reports the Multiple Linear Regression analysis for all companies in the sample. The R-squared $\left(\mathrm{R}^{2}\right)$ value indicates the percentage of the variation explained by the regression model on the group of indicator variables (Field, 2013). In this study, the value of $\mathrm{R}^{2}$ was 0.476 . Thus, the statistical result shows that the variation in independent variables explains $47.6 \%$ of the corporate reputation score changes: Total Integrated Reporting Disclosures Quality, Size, Board Size, Leverage, Financial and Non-Financial Companies and Year of the report.

Adjusted R-squared $\left(\mathrm{R}^{2}\right)$ can be explained as the variance in the outcome that the model explains in the population (Field, 2013). Also, the adjusted $\mathrm{R}^{2}$ value of 0.226 indicated that, on an adjusted basis, the independent variables were collectively $22.6 \%$ related to corporate reputation score. The F-statistics value of 17.197 showed a significant linear relationship between all the independent variables (TIRDQ, SIZE, BSIZE, LEV, IND and YR) and corporate reputation score. Furthermore, the 1.826 value for Durbin-Watson showed no autocorrelation, thus showing data independence between the independent variables to the corporate reputation score. The outcome showed that all independent variables were not correlated, which might have influenced the outcome of the analysis.

Table 4: Multiple Linear Regression Analysis

\begin{tabular}{lccc}
\hline \multicolumn{1}{c}{ Model } & Coefficient & t-value & p-value \\
\hline CONSTANT & 32.995 & 6.132 & 0.000 \\
TIRDQ & 0.105 & 9.281 & 0.000 \\
SIZE & -0.525 & -0.934 & 0.351 \\
BSIZE & 0.158 & 1.280 & 0.201 \\
LEV & -0.080 & -2.321 & 0.021 \\
IND & 3.901 & 3.272 & 0.001 \\
YR & 0.389 & 0.701 & 0.484 \\
R $^{2}$ & & .476 &
\end{tabular}




\begin{tabular}{lc} 
Adjusted $\mathrm{R}^{2}$ & 0.226 \\
F- statistics & 17.197 \\
P-value & .000 \\
Durbin-Watson & 1.826 \\
$\mathrm{~N}$ & 360 \\
\hline
\end{tabular}

In this study, hypothesis $\mathrm{H}_{1}$ was proposed to test whether there was a positive relationship between the quality of IR disclosure and the corporate reputation score. The findings showed that, for hypothesis $\mathrm{H}_{1}$, quality of the IR disclosure had a significant positive relationship with the corporate reputation score where the t-value for IR disclosure quality was 9.281 with a p-value of 0.000 . Corporate reputation was perceived as the most significant benefit of the IR since managers perceive it as a valuable tool for communicating corporate activities (Steyn, 2014). Preparing a high-quality IR will represent a response from the companies to the pressure connected with customers' information needs. In this perspective, the quality of IR disclosures will increase corporate image and reputation(Vitolla et al., 2019).

The finding showed that leverage had a significant negative relationship with corporate reputation where the $t$-value was at -2.321 with a $p$-value of 0.021 . This finding is consistent with a previous study that reputation significantly affects a firm's financing activity, where a higher reputation leads to lower financing constraints (Zhang et al., 2013). Further analysis showed that industry classification (financial and non-financial) had a significant positive relationship with the corporate reputation score where the $t$-value for the industry was 3.272 with a p-value of 0.001 .

\section{CONCLUSION}

Overall, the results between the TIRDQ and corporate reputation showed a significant positive relationship. The result confirmed previous findings that higher IR quality would improve corporate reputation (Armitage \& Marston, 2008; Giovanna et al., 2015; Steyn, 2014; Vitolla et al., 2019). A higher quality IR report will provide high-quality information to investors, which indirectly shows better internal decisions, which is rewarded through increased corporate reputation. Providing a high-quality IR report is a good practice of communication. Reputation for openness is valued because it enhances its overall reputation, bringing commercial benefits (Armitage \& 
Marston, 2008). These results also support the objective of the IIRC that the company reporting IR will be able to create value over time (IIRC, 2013b). The results of this study provide several implications for IR preparers, IIRC, and policymakers. First, IR preparers need to prepare a high-quality IR following 2013 IR Framework. Following IIRC recommendations, companies will disclose information regarding value creation activities in their IR, signalling a high-quality report. This information will increase corporate reputation since users will receive this signal as a connotation to management ethical reporting and provides a firm's positive characteristics (such as the right product or services). A positive corporate reputation is only possible with an ethical behaviour and trust-building with a firm's stakeholders. Firms that operate ethically in the long-term are expected to build a better reputation and achieve better performance due to better relationships with customers, suppliers, lenders, investors, and others.

Second, this has a regulatory implication for guiding the cost and benefits of adopting the IR. By documenting empirical evidence on whether the IR is value-enhancing to reporting companies, this study helps move the debate forward and incentivises voluntary adoption. This study is essential as it provides an understanding of the early stages of IR development, a new reporting model that represents a fundamental shift away from the traditional focus of corporate reporting.

This study is subject to a few limitations, such as the number of companies included as a sample because of the limited information available, especially regarding the reputation score. Future research might consider other ways of measuring the reputation of IR companies.

\section{REFERENCES}

Adam, C. A. (2017). Understanding Integrated Reporting: A concise guide to integrated thinking and future reporting. Routledge.

Adams, C. A. (2015). The International Integrated Reporting Council: A call to action. Critical Perspectives on Accounting, 27, 23-28. https:// doi.org/10.1016/j.cpa.2014.07.001 
Armitage, S., \& Marston, C. (2008). Corporate disclosure, cost of capital and reputation: Evidence from finance directors. The British Accounting Review, 40(4), 314-336. https://doi.org/10.1016/j.bar.2008.06.003

Arshad, R., Othman, S., \& Othman, R. (2012). Islamic corporate social responsibility, corporate reputation and performance. International Journal of Social, Behavioral, Educational, Economic, Business and Industrial Engineering, 6(4), 643-647.

Basdeo, D. K., Smith, K. G., Grimm, C. M., Rindova, V. P., \& Derfus, P. J. (2006). The impact of market actions on firm reputation. Strategic Management Journal, 27(12), 1205-1219. https://doi.org/10.1002/ smj.556

Brammer, S. J., \& Pavelin, S. (2006). Corporate reputation and social performance: The importance of fit. Journal of Management Studies, 43(3), 435-455. https://doi.org/10.1111/j.1467-6486.2006.00597.x

Bravo, F., Abad, C., \& Briones, J. L. (2015). The board of directors and corporate reputation: An empirical analysis. Academia Revista Latinoamericana de Administracion, 28(3), 359-379. https://doi. org/10.1108/arla-07-2013-0096

Charl de Villiers, P. J. P., de Villiers, C., Rinaldi, L., \& Unerman, J. (2014). Integrated reporting: Insights, gaps and an agenda for future research. Accounting, Auditing \& Accountability Journal, 27(7), 1042-1067. https://doi.org/10.1108/aaaj-06-2014-1736

Cortesi, A., \& Vena, L. (2019). Disclosure quality under Integrated Reporting: A value relevance approach. Journal of Cleaner Production, 220, 745-755. https://doi.org/10.1016/j.jclepro.2019.02.155

Darus, F., Othman, S., \& Arshad, R. (2014). Accountability and transparency of corporate social responsibility reporting and corporate reputation: Evidence from an Emerging Economy. In Proceedings of World Business And Economics Research Conference, Rendezvous Hotel, Auckland, New Zealand (24 - 25 February), 1-16. http:// www.wbiworldconpro.com/uploads/new-zealand-conference-2014/ accounting/1392795207_111-Roshyani.pdf 
Dolphin, R. R. (2004). Corporate reputation - A value creating strategy. Corporate Governance: The International Journal of Business in Society, 4(3), 77-92. https://doi.org/10.1108/14720700410547521

Eccles, R. G., \& Krzus, M. P. (2010). One report: Integrated reporting for a sustainable strategy. John Wiley \& Sons.

Field, A. (2013). Discovering Statistics Using SPSS SAGE.

Fombrun, C. J. (2005). Building corporate reputation through CSR initiatives: Evolving standards. Corporate Reputation Review, 8(1), $7-12$.

Fombrun, C. J., Ponzi, L. J., \& Newburry, W. (2015). Stakeholder tracking and analysis: The RepTrak ${ }^{\circledR}$ system for measuring corporate reputation. Corporate Reputation Review, 18(1), 3-24. https://doi.org/10.1057/ crr.2014.21

Galbreath, J., \& McDonald, G. (2010). How does corporate social responsibility benefit firms? Evidence from Australia. European Business Review, 22(4), 411-431. https://doi.org/10.1108/09555341011056186

Giovanna, M., Pilonato, S., \& Ricceri, F. (2015). CSR reporting practices and the quality of disclosure: An empirical analysis. Critical Perspectives on Accounting, 33, 59-78. https://doi.org/10.1016/j.cpa.2014.10.003

Hasseldine, J., Salama, A. I., \& Toms, J. S. (2005). Quantity versus quality: The impact of environmental disclosures on the reputations of UK Plcs. The British Accounting Review, 37(2), 231-248. https://doi. org/10.1016/j.bar.2004.10.003

IIRC. (2011). Communicating value in the 21st Century. Integrated Reporting (September), 17-17. Retrieved 1 March 2017, from www. theiirc.org

IIRC. (2013a). Capitals Background paper for $<$ IR >. 1-30. Retrieved 29 September 2014, from https://integratedreporting.org/wp-content/ uploads/2013/03/IR-Background-Paper-Capitals.pdf 
IIRC. (2013b). The International $<$ IR $>$ Framework. International Integrated Reporting Council. Retrieved 29 September 2015, from https://integratedreporting.org/wp-content/uploads/2021/01/ InternationalIntegratedReportingFramework.pdf

IIRC. (2014). Realizing the benefits: The impact of Integrated Reporting. Black Sun Plc, 1-28. Retrieved 1 March 2017, from https:// integratedreporting.org/resource/realizing-the-benefits-the-impact-ofintegrated-reporting/

Jensen, J. C., \& Berg, N. (2012). Determinants of traditional sustainability reporting versus integrated reporting. An institutionalist approach. Business Strategy and the Environment, 21(5), 299-316. https://doi. org/10.1002/bse. 740

Landgraf, E., \& Riahi-Belkaoui, A. (2003). Corporate disclosure quality and corporate reputation. Review of Accounting and Finance, 2(1), 86-95. https://doi.org/10.1108/eb027003

Love, E. G., Lim, J., \& Bednar, M. K. (2017). The face of the firm: The influence of CEOs on corporate reputation. Academy of Management Journal, 60(4), 1462-1481.

Oliveira, L., Rodrigues, L. L., \& Craig, R. (2010). Intangible assets and value relevance: Evidence from the Portuguese stock exchange. The British Accounting Review, 42(4), 241-252. https://doi.org/10.1016/j. bar.2010.08.001

Othman, R., Arshad, R., Aris, N. A., \& Arif, S. M. M. (2015). Organizational resources and sustained competitive advantage of cooperative organizations in Malaysia. Procedia - Social and Behavioral Sciences, 170, 120-127. https://doi.org/10.1016/j.sbspro.2015.01.021

Pavlopoulos, A., Magnis, C., \& Iatridis, G. E. (2019). Integrated reporting: An accounting disclosure tool for high quality financial reporting. Research in International Business and Finance, 49(February), 13-40. https://doi.org/10.1016/j.ribaf.2019.02.007 
Pham, H. S. T., \& Tran, H. T. (2020). CSR disclosure and firm performance: The mediating role of corporate reputation and moderating role of CEO integrity. Journal of Business Research, 120(January 2019), 127-136. https://doi.org/10.1016/j.jbusres.2020.08.002

Ponzi, L. J., Fombrun, C. J., \& Gardberg, N. A. (2011). RepTrak ${ }^{\mathrm{TM}}$ Pulse: Conceptualizing and validating a short-form measure of corporate reputation. Corporate Reputation Review, 14(1), 15-35. https://doi. org/10.1057/crr.2011.5

Reptrak. (2016). 2016 Corporate Reputation RepTrak ${ }^{\circledR}$ Pulse Results. South Africa's Most reputable companies. https://www.reputationinstitute.com

Roberts, P. W., \& Dowling, G. R. (2002). Corporate reputation and sustained superior financial performance. Strategic Management Journal, 23(12), 1077-1093. https://doi.org/10.1002/smj.274

Saeidi, S. P., Sofian, S., Saeidi, P., Saeidi, S. P., \& Saaeidi, S. A. (2015). How does corporate social responsibility contribute to firm financial performance? The mediating role of competitive advantage, reputation, and customer satisfaction. Journal of Business Research, 68(2), 341350. https://doi.org/10.1016/j.jbusres.2014.06.024

Spence, M. (1973). Job market signaling. Quarterly Journal of Economics 87, 281-306. https://doi.org/10.1016/b978-0-12-214850-7.50025-5

Steyn, M. (2014). Organisational benefits and implementation challenges of mandatory integrated reporting. Sustainability Accounting, Management and Policy Journal, 5(4), 476-503. https://doi.org/10.1108/ sampj-11-2013-0052

Toms, J. S. (2002). Firm resources, quality signals and the determinants of corporate environmental reputation: Some UK Evidence. The British Accounting Review, 34(3), 257-282. https://doi.org/10.1006/ bare.2002.0211

Vitolla, F., Raimo, N., \& Rubino, M. (2019). Appreciations, criticisms, determinants, and effects of integrated reporting: A systematic 
literature review. Corporate Social Responsibility and Environmental Management, 26(2), 518-528. https://doi.org/10.1002/csr.1734

Wang, K., \& Smith, L. M. (2008). Does corporate reputation translate into higher market value?, 35-35.

Zhang, F. H., Ma, X. W., Yang, W. H., \& Xu, Y. K. (2013). An empirical study on the relationships between entrepreneur and SMEs' vitality. 19th International Conference on Industrial Engineering and Engineering Management: Management System Innovation, 1443-1451. https://doi. org/10.1007/978-3-642-38427-1-153

Zhou, S., Simnett, R., \& Green, W. (2015). Does integrated reporting matter to the capital market? SSRN Electronic Journal, 53(1), 94-132. https:// doi.org/10.2139/ssrn.2600364 